\section{GASTRIC CYTOLOGY}

By R. O. K. Schade. Pp. viii +83 , illustrated. London: Edward Arnold Ltd. 1960. 35s.

In this monograph Dr. Schade gives a lucid and concise account of the principles, techniques and results of the study of exfoliated gastric cells, based on his considerable personal experience. It is concerned not only with the cytodiagnosis of gastric cancer, but also with the changes in 'gastritis,' pernicious anaemia and peptic ulceration. There are, furthermore, some interesting findings regarding the diagnosis of 'surface cancer.'

The difficulties of interpretation are not minimized and the need for properly prepared material stressed. The author's results show that this can be a very useful investigation in suitably experienced hands.

The text is easy to read and unencumbered with unnecessary detail and the illustrations are on the whole excellent but would have been more helpful for guidance of the less experienced cytologist if they had included figures of exfoliated normal gastric cells of all types, and of individual abnormal and malignant cells in addition to those found in groups or sheets.

The views expressed in the volume are the result of a great deal of personal experience and are well reasoned. Dr. Schade's book can be strongly recommended to clinicians and pathologists particularly interested in diseases of the stomach.

\section{SURGICAL ASPECTS OF MEDICINE}

Edited by H. Daintree Johnson, M.A., M.B., B.Chir., F.R.C.S. Pp. $\quad x v+382$. London: Butterworth \& Co. Ltd. I959. 65s.

This book, as its dust cover suggests, is a wellmixed surgical cocktail of medical subjects and problems compiled by a formidable group of authorities in their own subject.

It is easy to read and contains a fund of information for the practitioner, physician and surgeon. In addition, it should be invaluable for senior students, particularly those aspiring to higher qualification, as it presents an unusual and deliberately incomplete picture of many difficult aspects of applied surgical medicine.

The book may be picked up and a self-contained chapter read in a short time, leaving a clear picture of its subject matter and marked stimulus for further thought, and perhaps reading. The bibliography at the end of each chapter is very good.

I found the book as refreshing as it is disjointed, for it deals with equal care with circumcision, arterial reconstruction and painful feet, amongst many other interesting and practical problems.

In conclusion, the editor has succeeded admirably in his task and original purpose, to equate the surgical aspects of medicine, both in well-known and less frequented fields.

\section{SURGERY OF REPAIR AS APPLIED TO HAND INJURIES}

By B. K. Rank, C.M.G., M.S.(Melbourne), F.R.C.S.(Eng.), F.R.A.C.S., and A. R. WAKEFIELD, M.S.(Melbourne), F.R.C.S.(Eng.), F.R.A.C.S. Foreword by SIR Gordon GordonTAYLOR, K.B.E., C.B., LL.D., Sc.D., F.R.C.S., F.R.C.S.(Ed.), F.R.A.C.S., F.A.C.S., F.R.C.S. (Canada). Second edition. Pp. xiv +284 . Illustrated. Edinburgh and London: E. \& S. Livingstone Ltd. 1960. $45 \mathrm{~s}$.

A much welcomed textbook to those who deal with acute injuries of the hand. It is well laid out and I thoroughly appreciated the subdivision into five main sections. In this manner a much wider range of reader is catered for.

The first two parts are in particular of great value to the casualty officer, who has often to learn by bitter experience. Although not to be taken as a substitute for experience, this textbook will certainly guide the more junior surgeon along the right lines.

The remaining sections are of more specialized scope and will prove more helpful to those taking up a career in plastic or orthopaedic surgery.

Even so, this book as a whole is an excellent appraisal of the subject and a 'must' for any surgeon.

\section{A SHORT SYNOPSIS OF HUMAN PROTOZOOLOGY AND HELMINTHOLOGY}

By L. R. S. Macfarlane, O.B.E., M.D., M.A., D.P.H. Pp. vii $+25 \mathrm{I}$, illustrated. Edinburgh and London: E. \& S. Livingstone Ltd. 1960. 35 s.

Most appropriately this handbook comes from the distinguished centre of helminthology and protozoology at the Royal Army Medical College. It will surely never be forgotten that the great triumphs in these fields followed the pioneer work of the I.M.S. and R.A.M.C. in what was once the British Empire, and that the thriving infant states which inherit the tropics owe their present improved health and future hygienic prospects to those two organizations, and to the British Colonial Medical Service.

This is a severely practical laboratory vademecum, beautifully illustrated and dogmatically clear and concise. There is no doubt that it will be of the greatest service to all whose duty and sense of adventure calls them to the still exciting fields of medicine in the tropics.

\section{ESSENTIAL PRINCIPLES OF PATHOLOGY}

By J. W. Landells, M.A., M.B., B.Chir., M.R.C.P. Pp. 278. Illustrated. London: Pitman Medical Publishing Co. 1957. 25 s.

Most text-books are far too long. The trouble is 